Katarzyna Burska*

\title{
Kreatywność leksykalna w mediach
}

Według słowników języka polskiego kreatywny to „twórczy” (Szymczak [red.] 1999: 976), „zdolny do tworzenia czegoś nowego, oryginalny, twórczy” (Sobol [red.] 2000: 368), „mający zdolność tworzenia czegoś nowego, oryginalnego; dynamiczny i pomysłowy; dający taką zdolność; dający w efekcie coś nowego, oryginalnego; twórczy" (Dunaj [red.] 1996: 426). We wspó1czesnym świecie cecha ta jest niezwykle pożądana przez pracodawców, bycie kreatywnym jest niejako wymogiem dla osób ubiegających się o jakiekolwiek stanowisko. Kreatywność może dotyczyć wielu dziedzin ${ }^{1}$, w tym także języka.

" Mgr Katarzyna Burska - Uniwersytet Łódzki, Wydział Filologiczny, Katedra Współczesnego Języka Polskiego, al. Kościuszki 65, 90-514 Łódź.

${ }^{1} \mathrm{O}$ tym, że kreatywność jest cechą pożądaną w różnych branżach, świadczyć może chociażby fakt, że organizatorzy konkursu Jedź na Borussię z Bayernem następująco pisali o jego zasadach: „Wyślij nam zdjęcie, które przekona nas, że to właśnie Ty powinieneś wygrać bilet na mecz i obejrzeć go na żywo. Co powinno przedstawiać zdjęcie? Liczymy na waszą, czytelników Sport.pl i wielkich fanów sportu, kreatywność. Zaskoczcie nas, rozśmieszcie, zaimponujcie nam" [źródło: www.sport.pl/pilka/1,65081,11429082,Konkurs_Sport_pl_i_Eurosportu_2__ Jedz_na_Borussie.html, dostęp: 28.03.2012]. Liczne szkolenia mają na celu rozwijanie kreatywności, np. Instytut Filozofii i Wydział Nauk o Wychowaniu Uniwersytetu Łódzkiego prowadzily w marcu 2012 r. zapisy na pilotażowe szkolenie dla asystentów/adiunktów pod nazwą: Kreatywny asystent $\rightarrow$ kreatywny student. W zaproszeniu czytamy: „Kreatywność jest obecnie jedną z nieodzownych cech wykształconego człowieka i to zarówno w jego życiu zawodowym, jak i prywatnym. Otóż pracodawcy oczekują od absolwentów wyższych uczelni, że w sytuacjach problemowych wyjdą oni poza utarte schematy myślenia oraz działania i będą zdolni do nowatorskich rozwiązań powstałych kwestii. Twórcze podejście stało się również niezbędne w sferze pozazawodowej, ponieważ nasza droga życiowa nie przebiega już w ustalony od pokoleń sposób. Zmieniający się w zawrotnym tempie współczesny świat nieustannie stawia jednostkę w nowych sytuacjach. W radzeniu sobie w nich jest ona zdana wyłącznie na siebie, gdyż tradycyjne autorytety i modele postępowania utraciły dzisiaj swoją ważność. Ponadto wymogiem czasu stało się, że każdy ma nie tylko radzić sobie z nieprzewidywalnymi okolicznościami, ale - kierując się stałą tendencją do realizacji własnego potencjału - ma być 
Czym właściwie jest kreatywność leksykalna, jakie jej typy można wyróżnić, jakich tekstów może dotyczyć, w jakich celach jest używana?

Właściwości kreacyjne tkwią w samym języku. Renata Grzegorczykowa, próbując zdefiniować kreatywny charakter języka, podkreśliła, że „kreatywność albo przeciwstawiana jest automatyzmowi (odtwórczości), albo też oznacza stwarzanie nowych stanów rzeczy" (Grzegorczykowa 1995: 13). Barbara Kudra pojmuje kreatywność leksykalną dwuaspektowo: przedmiotowo-podmiotowo, czyli jako twórcze możliwości tkwiące w języku, oraz jako kreatywne możliwości podmiotu, wykorzystujące w tekście twórcze możliwości zawarte w języku w sposób świadomy, w określonej funkcji i celu (Kudra 2001a: 5).

Gdzie możemy zetknąć się z kreatywnością leksykalną? Media XXI w. oferują współczesnemu odbiorcy ogromnie wiele programów, konsument musi wybierać spośród milionów ofert reklamowych, czytelnikom proponuje się kilkaset tytułów gazet czy czasopism. Nagłówki, slogany czy nazwy muszą więc w jakiś sposób się wyróżniać, by przykuć uwagę. Niejednokrotnie dziennikarze, PR-owcy, copywriterzy, specjaliści do spraw marketingu i reklamy wykorzystują właśnie tworzywo językowe w celu wzbudzenia zainteresowania u potencjalnego widza, czytelnika czy klienta. Oryginalne formy leksykalne, zaskakujące aluzje, nietypowe połączenia frazeologiczne, zabawa grafią, sięganie po niekonwencjonalne skojarzenia, łamanie zasad łączliwości wyrazów, wplatanie elementów wizualnych do tekstu - to elementy szeroko pojmowanej gry językowej, mającej za zadanie zaciekawienie, zatrzymanie uwagi odbiorcy choć przez chwilę, czasem nawet szokowanie, a co za tym idzie - dotarcie do wyznaczonej grupy docelowej.

Niejako naturalnym środowiskiem występowania tworów leksykalnych mających kreatywny charakter będą teksty dziennikarskie - od tytułu rubryki, poprzez nagłówek, lid, śródtytuły, po zabiegi językowe wplatane do tekstu głównego. Szczególnie mocno jest to zauważalne w artykułach publicystycznych - autorzy felietonów i komentarzy mają dużą swobodę w wyrażaniu swoich poglądów, mogą więc bawić się słowem. Coraz powszechniejsze staje

twórcą samego siebie. Na kreatywność danej osoby oprócz warunków zewnętrznych składa się szereg czynników osobowościowych, mianowicie pewne postawy (np. otwartość, akceptowanie konfliktów i napięć, dążenie do rozwoju), aspekty działaniowe (jak umiejętność wykraczania poza przyjęte schematy, odwaga podejmowania wyzwań i nowatorskich rozwiązań), ale też wiedza. Zauważmy, że kreatywności nie warunkuje wyłącznie sfera intelektu, ale również emocje, motywacje i relacje interpersonalne. Zatem chcąc kształcić osoby kreatywne, nie należy skupiać się tylko na stronie erudycyjnej edukacji (tj. na dostarczaniu i egzekwowaniu wiedzy), ale należy również kształtować odpowiednie postawy i wyrabiać umiejętności, a tego nie uzyskuje się dzięki teorii, lecz dzięki nieustannym ćwiczeniom, dzięki praktyce" [informacje o szkoleniu pochodzą ze strony: www.uni.lodz.pl, dostęp: 7.03.2012]. 
się jednak wykorzystywanie kreatywności językowej nawet w artykułach informacyjnych - dziennikarze wiedzą, że odbiorcy, mając do wyboru wiele tytułów prasowych, nie są w stanie przeczytać wszystkiego i wybierają tylko to, co przyciąga ich uwagę, dlatego nawet informacja musi być podana w niespotykanej dotąd formie. Wbrew pozorom dbałość o oryginalny kształt językowy swoich wypowiedzi wykazują też piszący w czasopismach branżowych, specjalistycznych, które mają już ugruntowaną pozycję na rynku, cieszą się dużą popularnością i nie muszą przesadnie zabiegać o nowych czytelników - być może twórcy są jednak świadomi, że w dobie rozwoju nowych technologii, kiedy to publikacje internetowe zaczynają wypierać słowo drukowane, trzeba dbać o przywiązanie odbiorcy do konkretnego tytułu prasowego i od czasu do czasu zaskakiwać go niebanalnymi rozwiązaniami - w tym także językowymi.

Kreatywność leksykalna nie jest domeną wyłącznie dziennikarzy prasowych; skłonność do tworzenia neologizmów mają także osoby pracujące w telewizji czy radiu. Wyszukane połączenia wyrazowe możemy zaobserwować np. w nagłówkach telewizyjnych, czyli pisemnych zapowiedziach wydarzeń w serwisach informacyjnych. Na przełomie pierwszej i drugiej dekady XXI w. widz może wybierać spośród co najmniej kilkunastu programów mających w skrótowej formie podsumować najważniejsze wydarzenia w danym dniu. Coraz większą popularnością cieszą się także stacje informacyjne, w których wiadomości podawane są niemal bez przerwy. Praktycznie w każdym dzienniku pojawiają się takie same, najistotniejsze w danej chwili informacje i to właśnie sposób ich zaprezentowania zdecyduje o tym, które źródło poszerzenia wiedzy wybierze odbiorca. Ukazujące się na ekranie telewizora obrazy są niejednokrotnie identyczne, towarzyszy im zbliżony dźwięk, a zatem to warstwa słowna jest sposobem na wyróżnienie przekazu spośród wielu mu podobnych.

Prezenterzy radiowi mają chyba najmniejsze możliwości wykazania się pomysłowością $\mathrm{w}$ tworzeniu oryginalnych tworów słownych - nie dysponują wszak słowem pisanym, a jedynie mówionym, co nieco ogranicza ich twórcze możliwości. Nie znaczy to jednak, że nie stosują innowacyjnych połączeń leksykalnych.

Drugą bardzo dużą grupę nadawców wykorzystujących nietypowe pomysły w obrębie języka stanowią twórcy tekstów reklamowych - niezależnie od tego, w jakim medium emitowane są reklamy, trwają one zaledwie kilkadziesiąt sekund, a więc chwytliwy slogan jest niezbędnym elementem perswazyjnym. W takich komunikatach istotny jest dobór wszystkich elementów: słowo musi współgrać z dźwiękiem (w radiu, telewizji i Internecie) oraz obrazem (w prasie, telewizji i Internecie) lub kontrastować z nimi. Copywriterzy 
wiedzą, że trzeba zaskoczyć, zszokować odbiorcę ${ }^{2}$ - powtarzanie mało twórczych haseł, utartych schematów nie przyniesie zamierzonych efektów.

Kreatywność leksykalna jest immanentną cechą stylu artystycznego - pisarze, poeci, autorzy tekstów kabaretowych ${ }^{3}$ czy piosenek wykorzystują tworzywo słowne, by realizować cele estetyczne, bawić, wzruszać, manifestować swoje poglądy. Gry słowne używane w stylu artystycznym nie będą jednak przedmiotem niniejszego opracowania.

Społecznością wykazującą dużą aktywność w zakresie twórczego wykorzystywania zasobów leksykalnych języka jest bez wątpienia młodzież- w socjolektach uczniowskich czy studenckich nie brakuje oryginalnych nazw na określenie wszelkich elementów otaczającej nas rzeczywistości. Kreatywność leksykalna jest podstawą funkcjonowania wielu socjolektów; wydaje się, że największą rolę odgrywa jednak w tych o charakterze tajnym (por. Grabias 1980).

Medium, w którym nie brakuje innowacyjnych rozwiązań językowych, jest Internet. Szansę na manifestowanie swoich poglądów w niekonwencjonalnej formie stwarzają przede wszystkim blogi - współczesne formy dziennika służą wyrażaniu swoich myśli nie tylko przez przeciętnych obywateli, lecz także ludzi sławnych, np. sportowców, piosenkarzy, polityków, podróżników. Nierzadko posługują się oni neologizmami czy wyszukanymi połączeniami słownymi. Kreatywnych wpisów nie brakuje również na portalach społecznościowych. Przepływ informacji w sieci jest bardzo duży i następuje bardzo szybko - trzeba więc uczynić wszystko, by choć na chwilę zatrzymać uwage odbiorcy.

Kreatywnością muszą wykazywać się także autorzy nazw. Każdy nowy produkt czy firma muszą być nazwane w sposób wyjątkowy, pozwalający wyróżnić ofertę na tle konkurencji. Nazwa jest ponadto bardzo ważnym elementem wizerunkowym. Istotne, by była niepowtarzalna, unikatowa, a także zaskakująca - tak by odbiorca zwrócił uwagę na nasz towar.

Wiemy już, kto w sposób twórczy korzysta z tworzywa językowego, warto się zatem przyjrzeć rodzajom kreatywności leksykalnej. Można ją rozpatrywać na następujących płaszczyznach:

${ }^{2}$ To, jak bardzo doceniana przez konsumentów jest kreatywność w komunikatach reklamowych, potwierdza posługiwanie się połączeniami wyrazowymi pochodzącymi z komunikatów reklamowych w polszczyźnie codziennej, np. A swistak siedzi i zawija je w te sreberka; "Prawie” robi wielkq różnice, Nie dla idiotów, Dobrze posiedzieć przy żubrze, No to Frugo, Jest Crunchips, jest impreza, Takie rzeczy tylko w Erze.

${ }^{3}$ Por. Szczerbowski 1994. Autor sporo miejsca poświęcił szeroko rozumianej kreatywności językowej: modyfikacjom intertekstualnym jako sygnałom ironiczności, modyfikacjom przysłów jako wyznacznikom aluzji, skrzydlatym słowom, reinterpretacjom etymologicznym skrótowców. 
- frazeologia (w tym intertekstualność),

- słowotwórstwo (w tym grafia),

- fleksja,

- składnia,

- semantyka.

Zabiegi językowe polegające na modyfikacji frazeologizmów są zjawiskiem współcześnie bardzo popularnym ${ }^{4}$. Stanisław Bąba wszelkie przekształcenia związków frazeologicznych polegające na naruszeniu ich ustabilizowanej struktury nazywa innowacjami modyfikującymi. Dotyczą one zwłaszcza słownictwa, gdyż „struktura słowna frazeologizmu - jako mniej ustabilizowana jest tym samym podatniejsza na wszelkiego rodzaju zmiany i przetwarzanie" (Bąba 1989: 48). Badacz wyróżnił następujące procesy polegające na zmianie składu leksykalnego spetryfikowanych połączeń wyrazowych: uzupełnienie (innowacje rozszerzające), redukcja (innowacje skracające), wymiana komponentu (innowacje wymieniające), kontaminacja dwóch lub więcej frazeologizmów (innowacje kontaminujące) oraz innowacje regulujące (zmiany w zakresie kategorii liczby, strony, aspektu, zmiany słowotwórczej postaci wyrazu, zmiany w schemacie składniowym frazeologizmu).

Przejawem kreatywności językowej są tylko świadome modyfikacje ${ }^{5}$. Grażyna Majkowska definiuje je następująco: „to takie odstępstwo od normy, które da się uzasadnić funkcjonalnie i którego autor przewidział

${ }^{4}$ Do zabawy słowem zachęcała np. trwająca od 5 marca do 15 kwietnia 2012 r. akcja Pokaż jezyk!, organizowana przez jeden ze znanych polskich browarów. Organizatorzy konkursu nakłaniali: „Zmierz się z mistrzami słowa! Przerabiaj przysłowia i wymyślaj nowe. Zaskocz nas! Uruchom swoją wyobraźnię. Baw się słowem. Pokaż język! Liczy się pomysł i oryginalnośc” [źródło: www.zywiec.com.pl/\#/pokaz_jezyk, dostęp: 15.03.2012]. Zadania konkursowe polegały m.in. na przekształcaniu przysłów, łączeniu dwóch przysłów, tworzeniu przysłów z wykorzystaniem podanych słów, wymyślaniu nowych w oparciu o podany początek i koniec.

${ }^{5}$ Wielu badaczy zajmuje się funkcjami modyfikacji frazeologicznych, np. Grażyna Majkowska (1996a) skoncentrowała się na funkcjach związków frazeologicznych w publicystyce. Zauważyła, iż modyfikacje są wprowadzane w celach zwielokrotnienia sensu, prowokacji dwuznacznością, nadania żartobliwego charakteru. Częstym procesem jest wyzyskiwanie tytułu utworu literackiego czy filmu w funkcji obiegowego wyrażenia lub zwrotu. Funkcje frazeologizmów i ich formalno-znaczeniowych przekształceń w telewizyjnych programach publicystycznych prześledziła zaś Katarzyna Jachimowska (2001). Uzupełnienie składu, redukcja elementu, wymiana komponentów bądź kontaminacja służą osiągnięciu celów perswazyjnych, wzmocnieniu ekspresji lub wywołaniu efektów komicznych. Z kolei Beata Burska-Ratajczyk (2006), analizując felietony Krzysztofa Skiby, spostrzegła, że modyfikacje formalne frazeologizmów mają wpływ na emocjonalną wartość wypowiedzi; kanoniczne wykorzystanie związku wyrazowego, ale przede wszystkim wszelkie odchylenia od normy frazeologicznej mogą być źródłem komizmu, służą wzmocnieniu ekspresji słownej, przyciągają uwagę czytelnika, pomagają kształtować ocenę i waloryzować. 
konsekwencje wpływu naruszenia normy frazeologicznej na semantyczny i stylistyczny kształt wypowiedzi" (Majkowska 1998: 143-144). Badaczka ustaliła kryteria decydujące o tym, czy dane naruszenie treści i formy związku frazeologicznego jest celowe: umieszczenie innowacji w specjalnie zbudowanym kontekście; zastosowanie modyfikacji przesadnej, uderzającej, zwracającej uwagę odbiorcy wyraźnym naruszeniem struktury formalnej i znaczeniowej; widoczna gra znaczeń (przenośnego i dosłownego); jednostkowość, niepowtarzalność (w przeciwieństwie do seryjności, typowej dla modyfikacji niezamierzonych); intencja nadawcy - celowe użycie takiego chwytu w tekście publicystycznym.

Donata Ochmann, przeprowadzając formalny podział kontaminacji, wyróżniła także kontaminacje frazeologiczne, do których zaliczyła kontaminacje frazeologizmu $z$ wyrazem ( $z$ węzłem i węzłem zerowym), włączenie wyrazu do kontaminacji oraz kontaminacje dwóch frazeologizmów (Ochmann 1997: 131-144). Krzyżowanie związku frazeologicznego z wyrazem następuje w wyniku wymiany jednego komponentu na inny, który mówiącemu wydaje się atrakcyjniejszy od występującego w danym frazeologizmie. Nowo wprowadzana jednostka leksykalna może być podobna (brzmieniowo lub semantycznie) do tej, którą zastępuje, lub całkowicie się od niej różnić.

Ciekawym zagadnieniem jest palimpsestowość ${ }^{6}$ tekstów medialnych, polegająca na wieloznacznym, wielowarstwowym i wielopoziomowym odczytywaniu wypowiedzi. Nowy twór językowy jest budowany na bazie już istniejącego. „Palimpsest słowny powstaje w wyniku takiego formalnego i znaczeniowego przekształcenia tekstu znanego przeciętnemu użytkownikowi, aby nowy tekst, przekazując nową informację, wykorzystywał jednocześnie nośność tekstu pierwotnego" (Kacprzak 2002: 46). Zdaniem Grażyny Majkowskiej

związki frazeologiczne to jeden z wielu językowych sposobów (chwytów) wyrażania aluzji, ale także parodii czy pastiszu oficjalnego języka propagandy, a ponadto środek manifestowania niezależności, w tym także językowej, autora felietonu, który pozostając w kulturze mass mediów, poprzez felieton chce wyrazić swoje literacko-publicystyczne ja (Majkowska 1998: 148).

Dziś, kiedy nie obowiązuje już cenzura, a autorzy mają pełną swobodę wypowiedzi, nie ma potrzeby ukrywania swoich poglądów, ale i tak chętnie wykorzystuje się kontaminacje frazeologiczne w celu kreowania samoświadomości twórcy.

${ }^{6}$ Palimpsest to starożytny lub średniowieczny rękopis pisany na pergaminie, z którego wytarto tekst pierwotny (def. za: Bralczyk [red.] 2005: 530). 
Aby lepiej zobrazować, na czym polega kreatywność leksykalna w obrębie frazeologii, warto przytoczyć kilka przykładów. Chyba najczęściej występującym przekształceniem są innowacje wymieniające:

Nr 1: Jak trwoga to do Ujka - o kierowaniu piłek przez zawodników PGE GKS-u Bełchatów do Mariusza Ujka (PN 13/2009, s. 18); jak trwoga, to do Boga (przysł. 'dopiero nieszczęście, krytyczna sytuacja skłania ludzi do modlitwy', WSF, s. 567) + Ujka.

Do dwóch razy sztuka - o Marcie Nowickiej, która została laureatką konkursu „Grasz o staż” po porażce w poprzednim roku (GW Praca 24/2009, s. 4); do trzech razy sztuka (przysł. 1. 'coś może się udać za trzecim razem', 2. 'coś może się udać tylko dwa razy z rzędu', WSF, s. 436) + dwóch.

STRIPS DODAĆ, NIC UJĄĆ! - billboard reklamowy sieci restauracji KFC, oferujących czwarty strips w prezencie do zestawu Strips menu; nic dodać, nic ująć ('zwrot okréslający doskonałość, trafność jakiejś wypowiedzi; doskonale, trafnie, bez zarzutu', WSF, s. 72) + strips.

Ostatni blog ratunku - o blogach sławnych ludzi jako coraz częściej jedynym sposobie na podtrzymanie zainteresowania ich osobami (W 7/2009, s. 102); ostatnia, jedyna deska ratunku ('coś, co może uratować, lub ktoś, kto może pomóc w trudnej sytuacji', WSF, s. 66) + blog.

Za mundurem księża sznurem - o dwudziestoleciu ordynariatu polowego w polskiej armii (P 5/2011, s. 1); za mundurem panny sznurem (przysł. 'wojskowi mają powodzenie u kobiet', WSF, s. 260) + księża.

Uzupełnienie składu leksykalnego spetryfikowanego połączenia wyrazowego może przybierać różną formę - dodatkowy wyraz może poprzedzać frazeologizm, rozbijać go lub być dopowiedzeniem, dopełnieniem - wówczas pojawia się po związku frazeologicznym:

Zdrowy kłębek nerwów - o badaniach dowodzących, że stres zwiększa długość życia i korzystnie wpływa na organizm (W 34-35/2009, s. 52); kłębek nerwów ('o człowieku bardzo nerwowym, znerwicowanym', WSF, s. 171) + zdrowy.

Gorączka arktycznego złota - o sporze nt. przynależności Arktyki (GW 29-30.11.2008, s. 32); gorączka złota (1. 'pęd do poszukiwań pokładów złota', 2. 'pogoń za zyskiem, za zwiększonymi dochodami', WSF, s. 124) + arktycznego.

Syn marnotrawny Berlusconiego - o powrocie Andrija Szewczenki do Milanu, którego właścicielem jest Silvio Berlusconi (PN 35/2008, s. 33); syn marnotrawny ('ktoś, kto zawinił lub zbłądził, ale w końcu się opamiętał', WSF, s. 233) + Berlusconiego.

${ }^{7}$ Objaśnienia związków frazeologicznych pochodzą z publikacji: A. Kłosińska, E. Sobol, A. Stankiewicz (red.), Wielki stownik frazeologiczny PWN z przystowiami, Warszawa 2009 (skrót: WSF; po przecinku podano numer strony). 
Zdarza się, że stałe związki rozszerzane są o więcej niż jeden wyraz, np.:

KOMU W DROGE, TEMU... CZAS DECYDOWAĆ DOKĄD! - reklama prasowa biura podróży Triada; komu w drogę, temu czas (przysł. 'wezwanie do odejścia skądś, wyruszenia w drogę', WSF, s. 82) + decydować + dokąd.

Serce nie sługa, nie poczeka - o konieczności jak najszybszego wezwania pomocy do chorego z zaburzeniami rytmu serca (P 14/2011, s. 76); serce nie sługa (nie wie, co to pany) ('nie można się zmusić do kochania kogoś, WSF, s. 471) + nie poczeka.

Zabieg fonetycznego podobieństwa wymienianych członów zastosowano, łącząc frazeologizmy: iść łeb w łeb (pot. 1. 'o zwierzętach, zwłaszcza koniach wyścigowych: biec, galopować równo, nie prześcigając jeden drugiego’, 2. 'o ludziach podczas jakiejś rywalizacji: mieć przez cały czas takie same wyniki', WSF, s. 224) z nazwiskiem angielskiego sędziego piłkarskiego, a także: mieć głowę, pot. łeb (na karku), mieć głowę (nie od parady) ('być mądrym, sprytnym, umieć sobie radzić', WSF, s. 242) - z nazwą własną sieci. Dodatkowo w poniższych połączeniach doszło do redukcji członu czasownikowego wchodzącego w skład związku frazeologicznego:

Łeb w Webb - o zrzucaniu winy za porażkę Polaków w meczu z Austrią na sędziego Howarda Webba i niedopuszczaniu myśli o słabej postawie naszej drużyny (PN 26/2008, s. 47), iść teb w teb + Webb [uep].

Webb w leb - o angielskim arbitrze Howardzie Webbie, który w ostatniej minucie meczu Brazylia - Egipt zmienił swoją decyzję i podyktował rzut karny zamiast rożnego (PN 25/2009, s. 43); iść łeb w łeb + Webb [uep].

Web na karku - o nadejściu Web 3.0, ery myślącego Internetu (P 13/2011, s. 50); mieć głowę, pot. łeb (na karku), mieć głowę (nie od parady) + Web [ựep].

$\mathrm{Z}$ innowacją skracającą i jednocześnie wymianą komponentów mamy do czynienia w przykładach:

Nie taki Ebi straszny... - o Euzebiuszu Smolarku, który zgodził się na złożenie autografu oraz zrobienie zdjęć z kibicami (PN 25/2008, s. 29); nie taki diabeł straszny, jak go malują (przysł. 'coś okazuje się nie tak trudne, jak się początkowo zdawało', WSF, s. 67) + Ebi.

Jak bielik z popiołów - o orle bieliku, który był bliski wyginięcia, a teraz się odrodził i pomaga odbudować gatunek w Anglii i Izraelu (P 10/2011, s. 64); powstać, odrodzić się jak Feniks z popiołów ('powstać od nowa po całkowitym zniszczeniu', WSF, s. 101).

Możliwe jest łączenie nawet trzech różnych typów innowacji - w poniższym sloganie wykorzystano jednocześnie rozszerzenie i skrócenie przysłowia, a także wymianę elementu wchodzącego w jego skład:

E-WEEK - nie taka mysz straszna! - reklama internetowa cyklu szkoleń z zakresu m.in. e-biznesu, grafiki i programowania, skierowanego do studentów wrocławskich uczelni; nie taki 
diabeł straszny, jak go malują (przysł. 'coś okazuje się nie tak trudne, jak się początkowo zdawało', WSF, s. 67) + mysz + e-week.

Kontaminacje dwóch związków frazeologicznych pojawiły się w nagłówkach prasowych:

Miej oko na oku - o konieczności dbania o wzrok (P 48/2009, s. 84); mieć oko na kogoś, coś (1. 'pilnować, strzec kogoś, czegoś, czuwać nad kimś', 2. 'obserwować kogoś, być ostrożnym, czujnym w stosunku do kogoś', WSF, s. 316) + mieć kogoś, coś na oku ('przypominać lub wyobrażać sobie kogoś, coś', WSF, s. 315).

Oddam w czyste ręce - o nowej ustawie o partnerstwie publiczno-prywatnym, mającej pomóc w wyprzedaży gminnych majątków (P 6/2009, s. 27); dać, oddać coś w dobre, pewne ręce; zostawić kogoś w dobrych, pewnych rękach ('powierzyć coś lub kogoś dobrej, uczciwej, zaufanej osobie', WSF, s. 439) + mieć czyste ręce, być człowiekiem czystych rąk ('być człowiekiem uczciwym, nie mieć na sumieniu żadnych niezgodnych z prawem czynów', WSF, s. 53).

Innym, poza związkami frazeologicznymi, schematem językowym zakorzenionym w świadomości odbiorców, który podlega twórczym przekształceniom, są tytuły bądź fragmenty piosenek, filmów czy książek. Wiąże się to $\mathrm{z}$ zagadnieniem intertekstualności. Termin ten został wprowadzony przez Julię Kristevą w 1969 r. W znaczeniu ogólnym obejmuje rozmaite występujące w danym utworze nawiązania lub odniesienia do innego dzieła. Podstawa było założenie, że nie można analizować struktury tekstu, jeśli nie sytuuje się jej w taki czy inny sposób wobec innych tekstów (Głowiński 1992: 87). Nie wszystkie zależności między tekstami można rozpatrywać w kategoriach relacji intertekstualnych. W tę sferę wchodzą takie relacje $z$ innymi utworami, które stały się elementem strukturalnym lub znaczeniowym (semantycznym) (Głowiński 1992: 91); są zabiegiem świadomym i zamierzonym, przeznaczonym dla czytelnika, który potrafi rozpoznać, że nadawca mówi nie swoim tekstem (Kudra B., Kudra A. 2002: 501); uchwycić pozycję danego utworu w abstrakcyjnej przestrzeni, w której sąsiaduje on $\mathrm{z}$ innymi tekstami. Jak stwierdza Michał Głowiński:

praktyki intertekstualne zakładają nie tylko, że dane odniesienia tekstowe zostaną odczytane i że również odbiorcy przyznają im pożądaną wartość, zakładają także oddziaływanie na sposoby lektury. Intertekstualność staje się swoistym wyzwaniem wobec czytelnika (Głowiński 1992: 121-122).

Zjawiska wchodzące w zakres intertekstualności Maria Renata Mayenowa określiła jako wyrażenia cudzysłowowe ${ }^{8}$. Gérard Genette zaproponował

\footnotetext{
${ }^{8}$ Cyt. za: Głowiński 1992: 91.
} 
następującą definicję intertekstualności: „rzeczywiste występowanie tekstu w tekście" ${ }^{9}$. Obejmuje ona cytaty i aluzje. Badacz za pojęcie nadrzędne uznał transtekstualność, w której obrębie wyróżnił pięć podstawowych typów, w tym wspomnianą intertekstualność.

Intertekstualne nawiązania podlegają tym samym przekształceniom co frazeologizmy. Modyfikacje dotyczą tytułów, np.:

W poszukiwaniu straconych złudzeń - o powodach, dla których warto przychodzić na mecze polskiej ekstraklasy piłkarskiej (PN 30/2009, s. 4), W poszukiwaniu straconego czasu (tytuł cyklu powieściowego Marcela Prousta) + złudzeń.

Co z tym Polską - o Manueli Gretkowskiej, przewodniczącej Partii Kobiet, która dwa lata temu stwierdziła, ze Polska jest kobietą, a teraz nazywa ją facetem (P 48/2009, s. 108); Co z ta Polska? (tytul programu telewizyjnego prowadzonego przez Tomasza Lisa, emitowanego w telewizji Polsat) + tym.

Gorączka karnawałowej nocy - o dużej liczbie balów karnawałowych w Europie tuż przed Środą Popielcową (W 8/2009, s. 120); Gorączka sobotniej nocy (tytuł filmu Johna Badhama) + karnawałowej.

O jeden lot za daleko - wywiad z Filipem Ivanovskim (PN Plus 1/2009, s. 25); O jeden most za daleko (tytuł książki Corneliusa Ryana, a następnie jej ekranizacji dokonanej przez Richarda Attenborougha) + lot.

Sen nocy wielkiej - o śnie Jana Turnaua w nocy z 5 na 6 czerwca 1989 r. (M 5.06.2009, s. 7); Sen nocy letniej (tytuł komedii Wiliama Szekspira) + wielkiej.

Pisać każdy może - o byciu pisarzem z bezsilności, w celu odzyskania spokoju (P 6/2009, s. 90); Śpiewać każdy może (tytuł piosenki Jerzego Stuhra) + pisać.

Alicja w krainie smakołyków - o podróży do Genussregion w Austrii i możliwości spróbowania lokalnych potraw (GW Turystyka 39/2009, s. 6); Alicja w krainie czarów (tytuł książki Lewisa Carolla) + smakołyków.

Badanie na śniadanie - o nowoczesnych metodach wykrywania chorób (P 5/2009, s. 68); Pytanie na śniadanie (tytul programu porannego emitowanego w TVP2) + badanie.

LOEB REAKTYWACJA - o dobrym wyniku Loeba w rajdzie Polski po wypadnięciu z trasy dzień wcześniej (Sport TVP1, 27.06.2009); Matrix: reaktywacja (tytuł filmu Andy'ego i Larry'ego Wachowskich) + Loeb.

Wymianie czy rozszerzeniu ulegają także fragmenty piosenek czy utworów literackich, a nawet modlitw:

Deszcze niespokojne potargają Sepang - o spodziewanych opadach deszczu podczas Grand Prix Malezji na torze w Sepang (GW 31.03.2009, s. 26); „Deszcze niespokojne potargały sad" (fragment piosenki Deszcze niespokojne Edmunda Fettinga) + Sepang.

Im strzelać nie kazano - o nieskutecznych napastnikach Legii Warszawa (GW Sport 33/2009, s. 4); „Nam strzelać nie kazano” (fragment Reduty Ordona Adama Mickiewicza) + im.

\footnotetext{
${ }^{9}$ Tamże, s. 94.
} 
Jeszcze Polska (gospodarka) nie zginęła - o wzroście PKB w Polsce o 0,8\% w pierwszym kwartale 2009 r. (GW 30-31.05.2009, s. 1); „Jeszcze Polska nie zginęła” (fragment polskiego hymnu narodowego) + gospodarka.

Nic trzy razy się nie zdarza - o wygranej Chelsea Londyn w półfinałowym pojedynku Ligi Mistrzów z Liverpoolem po dwóch porażkach w poprzednich latach (PN 21/2008, s. 21); „Nic dwa razy się nie zdarza” (fragment wiersza Wisławy Szymborskiej Nic dwa razy) + trzy.

Transfery czas zacząć - o rozpoczęciu letniego okienka transferowego w lidze polskiej (PN 25/2009, s. 3); „Poloneza czas zacząć” (fragment Pana Tadeusza Adama Mickiewicza) + transfery.

Wsiądź do pociągu... byle naszego! - reklama prasowa wakacyjnych wyjazdów z PKP Intercity; „Wsiąść do pociągu byle jakiego” (fragment piosenki Remedium Maryli Rodowicz) + naszego + wsiądź.

W IMIĘ OJCA I SYNA, I DUCHA ŚWIĘTEGO, ENTER - o ojcu Zdzisławie Pałubickim, 73-letnim jezuicie, pierwszym w Polsce księdzu proponującym odprawianie pokuty przez Internet (GW 14.03.2008, s. 13); „W imię Ojca, i Syna, i Ducha Świętego. Amen” + Enter.

$\mathrm{Na}$ uwagę zasługuje nagłówek, w którym doszło do połączenia tytułów dwóch seriali produkowanych w różnych krajach; zabieg ten współgra z tematyką artykułu:

Gotowe na wszystko w opalach - o polskich wersjach zachodnich seriali (W 34-35/2009, s. 78), Gotowe na wszystko (tytuł amerykańskiego serialu telewizyjnego) + Hela w opatach (tytuł polskiego serialu telewizyjnego).

Drugim, obok frazeologicznej, niezwykle często wykorzystywanym typem jest kreatywność słowotwórcza. Jej przejawem może być wykorzystywanie kontaminacji. Jak definiuje Donata Ochmann: „kontaminacja leksykalna jest rodzajem kompozycji, polegającym na skrzyżowaniu (przeważnie) dwu całych lub fonicznie uszczuplonych jednostek leksykalnych w jedną całość strukturalną, najczęściej zawierającą cząstkę wspólną dla obu komponentów" (Ochmann 1997: 132). Nowo powstała jednostka może mieć jeden element wspólny dla obu komponentów lub więcej, choć występują też kontaminacje z węzłem zerowym. Węzeł kontaminacyjny może pojawiać się w nagłosie, śródgłosie i wygłosie. Zjawisko krzyżowania jednostek leksykalnych obrazują następujące przykłady:

Celebrytuat - o ślubie Kate Middleton i księcia Williama oraz beatyfikacji Jana Pawła II jako wydarzeniach mających rytualną oprawą i nawiązujących do prawzorca świata celebry (P 19/2011, s. 10); celebra + rytuał.

Technikum Duchowlane - o braku porozumienia między Kościołem a artystami i intelektualistami w Polsce (P 16/2011, s. 21); duchowny + budowlane. 
TESTOLATKI - o uczniach szkół podstawowych, gimnazjów i szkół średnich, którzy poddawani są egzaminom w formie testów (P 19/2011, s. 1); test + nastolatki.

Tragikomiks - o antologii komiksowej Chopin New Romantic, wydanej z okazji Roku Chopinowskiego, zawierającej wulgarne słowa (P 10/2011, s. 32); tragikomizm + komiks.

Wielki ComeBock - billboard reklamowy piwa Bock; comeback (ang. 'powrót') + Bock.

Interesującym procesem jest wykorzystanie do kontaminacji homofonów. Kwestia zapisu odgrywa niezwykle istotną rolę w słowach, których brzmienie jest identyczne, ale mają odmienną pisownię i w związku $\mathrm{z}$ tym - inne znaczenie. Znając tylko fonetyczną postać wyrazów, nie bylibyśmy w stanie dostrzec zjawiska krzyżowania wyrazów w poniższych nagłówkach czy sloganach. Kontaminacje opierają się na tożsamości brzmieniowej, dopiero zapoznanie się z zapisem umożliwia odbiorcy dostrzeżenie gry słownej:

CZTERY DNI W ROCKU - o festiwalu muzycznym w Roskilde w Danii, w którym uczestniczyło 100 tys. fanów (WO 33/2009, s. 23); roku + rocku.

Efect psychologiczny - o firmie Efect Doradztwo Finansowe, stosującej chwyty psychologiczne w zdobywaniu nowych klientów (GW Pieniądze 3/2009, s. 4); efekt + Efect.

Good LACK! - reklama prasowa stolika o nazwie LACK, dostępnego w sklepie Ikea; good luck! (ang. 'powodzenia') + Lack.

GÓRALU, WRACAJ DO HALL ${ }^{10}$ - o krytyce resortu edukacji na czele z minister Katarzyną Hall, który ujednolicił wszystkie egzaminy końcowe (GW 4-5.07.2009, s. 26); hal + Hall.

Panie przodem, panowie na Bock - billboard reklamowy piwa Bock; bok + Bock.

Stary człowiek i może - o romansie 68-letniego reżysera Andrzeja Żuławskiego z młodszą o 44 lata Weroniką Rosati (W 33/2008, s. 106); Stary cztowiek i morze (tytuł utworu Ernesta Hemingwaya) + może.

Tour de Franz - o wyborze Franciszka Smudy na selekcjonera piłkarskiej reprezentacji Polski (PN Plus 12/2009, s. 4); Tour de France (nazwa wieloetapowego wyścigu kolarskiego rozgrywanego na terenie Francji) + Franz (pseudonim selekcjonera piłkarskiej reprezentacji Polski Franciszka Smudy).

Bywa i tak, że dla dostrzeżenia kontaminacji niezbędne jest zapoznanie się z formą graficzną neologizmu, choć kontaminowanymi formami nie są homofony - dzieje się tak np. wówczas, gdy krzyżujemy litery z cyframi, wyrazy ze skrótowcami czy dwa wyrazy (wtedy krótszy zapisany jest majuskułami):

Dołącz do programu „4 pory roku” na rossnet.pl i ROSSpraw się z zimą - reklama drogerii Rossman zachęcająca do zapoznania się z zimowymi wskazówkami i atrakcyjnymi rabatami na stronie internetowej; Rossman + rozpraw.

${ }^{10} \mathrm{~W}$ tym przykładzie posłużono się również intertekstualnym nawiązaniem do fragmentu piosenki Góralu, czy ci nie żal: „Góralu, wracaj do hal”. 
MONey - o braku pieniędzy dla MON (FTVN, 19.01.2009); money (ang. 'pieniądze') + MON.

obraz POkontrolny - o ustawie medialnej dotyczącej kontroli mediów publicznych, którą popiera PO, przeciwne zaś są SLD i PiS (F TVN, 23.06.2009); pokontrolny + PO.

OFErta - o zmianach $\mathrm{w}$ świadczeniach emerytalnych i przesunięciu części pieniędzy z Otwartego Funduszu Emerytalnego do ZUS-u (F TVN, 04.11.2009); oferta + OFE.

Otrzaskani z PISA-niem - o dobrych wynikach testu PISA, czyli Międzynarodowej Oceny Umiejętności Uczniów, wśród polskich nastolatków, według wielu będących efektem nieustannego sprawdzania wiedzy w formie testów (P 19/2011, s. 14).

Raz, że szybko, A2, że do Europy - hasło reklamowe firmy Autostrada Wielkopolska II SA, promujące otwarcie nowego odcinka autostrady A2 z Nowego Tomyśla do Świecka; a dwa + A2.

wSPAniała morska kąpiel w domu - reklama prasowa kosmetyków z Morza Martwego Mineral Care SPA; wspaniały + SPA.

wyPISka - o politykach Prawa i Sprawiedliwości tworzących listę swoich nowych sojuszników, którzy wcześniej byli zwolennikami Platformy Obywatelskiej (P 12/2011, s. 28).

Szczególnym rodzajem kontaminacji jest rozwinięcie skrótowców wprowadzające w pełnej nazwie jakąś zmianę. Jak zauważa Donata Ochmann,

powstają wprawdzie w ten sposób nowe nazwy utworzone według pewnego wzoru (a całą operację można w nieskończoność powtarzać), ale w samej strukturze zawierają inną nazwę: jej rozwijany skrót, a często i więcej elementów. Pozostała część kontaminacji (wyraz albo ich grupa) spełnia oczywiście warunek fonetycznej i (lub) graficznej zbieżności z pierwszym komponentem (owym skrótem lub jego częścią) (Ochmann 1997: 140).

Reinterpretacja akronimów jest swoistą grą formą leksykalną. Może mieć cechy etymologii ludowej, czyli błędnego, sprzecznego z dokumentacją językoznawczą wyjaśniania pochodzenia określonego wyrazu (często zapożyczonego $z$ innego języka) poprzez wtórne przekształcenie jego brzmienia na wzór znanych wyrazów rodzimych (Głowiński i in. 2000: 144). Zjawisko reinterpretacji etymologicznej cieszy się popularnością twórców tekstów kabaretowych, którzy uzyskują dzięki niemu efekt komiczny. Zabieg ten chętnie jest wykorzystywany także przez autorów napisów na murach - graffiti ${ }^{11}$. Nietypowe rozwinięcia skrótowców można odnaleźć także w nagłówkach prasowych:

AKADEMIE WYZYSKU FINANSOWEGO - o pozornie bezpłatnych studiach na publicznych uczelniach (DF 39/2009, s. 11); Akademia Wychowania Fizycznego + Wyzysku Finansowego.

Centralna Karuzela Egzaminacyjna - o ósmej już zmianie personalnej w Centralnej Komisji Egzaminacyjnej (P 30/2008, s. 7); Centralna Komisja Egzaminacyjna + Karuzela.

${ }^{11}$ Por. Guz 2001: 17. 
MPK, czyli Miejski Paraliż Komunikacyjny - o zmianach w komunikacji miejskiej, które wywołały chaos wśród mieszkańców Łodzi (GW Łódź 2.07.2009, s. 1); Miejskie Przedsiębiorstwo Komunikacyjne + Paraliż.

Opieszały Fundusz Emerytalny - o stratach poniesionych przez klientów OFE w 2008 r., mających wpływ na obniżenie ich przyszłych emerytur (W 39/2009, s. 48); Otwarty Fundusz Emerytalny + Opieszały.

Polska ANEMIA NAUK - raport czterystu polskich naukowców nt. stanu nauki i szkolnictwa wyższego (GW 11.02.2008, s. 1); Polska Akademia Nauk + Anemia.

POLSKA RZECZPOSPOLITA LUDYCZNA - o walce bokserów Adamka i Gołoty jako ilustracji życia publicznego w Polsce, czyli mordobicia publicznego (GW 29.10.2009, s. 20); Polska Rzeczpospolita Ludowa + Ludyczna.

Zakład Użytkowania Staroci - o zapisywaniu danych w ZUS-ie na wychodzących dziś z użycia dyskietkach (GW 18.11.2008, s. 2); Zakład Ubezpieczeń Społecznych + Użytkowania Staroci.

Niektóre skrótowce są chętnie wykorzystywane przez dziennikarzy i możemy zaobserwować ich różnorodne żartobliwe modyfikacje w nagłówkach prasowych. Niewątpliwie należy do nich PKP:

PIĘKNIE, K..., PIĘKNIE - o zdenerwowanych pasażerach PKP, czekających na spóźniony pociąg i odbywających podróż w nieogrzewanych wagonach (GW Łódź 8.01.2009, s. 4); Polskie Koleje Państwowe + Pięknie + K...

Polskie Koleiny Państwowe - o likwidowaniu torów kolejowych przez PKP (W 3/2009, s. 64); Polskie Koleje Państwowe + Koleiny.

Polskie Koleje Poukładane - o zwycięstwach spółki PKP Przewozy Regionalne w przetargach na obsługę kolejowych połączeń pasażerskich organizowanych przez samorządy wojewódzkie (W Extra 39/2009, s. 100); Polskie Koleje Państwowe + Poukładane.

Nie brakuje także kreatywnych pomysłów na rozszyfrowanie akronimów odnoszących się do partii politycznych:

Schronisko Demokratyczne - o historii Stronnictwa Demokratycznego i najbliższym celu: wypromowaniu Andrzeja Olechowskiego w wyborach prezydenckich (DF 13/2009, s. 6-7); Stronnictwo Demokratyczne + Schronisko.

Stronnictwo Drzemiących - o przejęciu władzy w Stronnictwie Demokratycznym przez Pawła Piskorskiego i popularności ugrupowania dochodzącej do jednego procenta (P 5152/2009, s. 8); Stronnictwo Demokratyczne + Drzemiących.

Sojusz od Lewicy Daleko - o wynikach ankiet przeprowadzanych wśród działaczy SLD, odbiegających od poglądów lewicy (GW 18.11.2008, s. 4); Sojusz Lewicy Demokratycznej + Daleko.

W większości przykładów rozwinięcie skrótowców nadaje pierwotnej nazwie instytucji, urzędu, partii politycznej itp. znaczenie pejoratywne; wprowadzane są wyrazy, które jednoznacznie konotują negatywne treści: wyzysk, paraliż, opieszaty, 
anemia, starocie, drzemiacy czy koleiny. Raz nawet posłużono się wielokropkiem w celach eufemizacyjnych, oznaczając w ten sposób wulgaryzm (PIEKNIE, $K$..., PIĘKNIE). Często zdarza się, że nietypowe rozszyfrowanie skrótowców ma na celu zaktualizowanie treści, jest reakcją (najczęściej ujemną, degradującą) na zaistniałe wydarzenia.

Kreatywność słowotwórcza może się także przejawiać w tworzeniu neologizmów rzeczownikowych, przymiotnikowych czy czasownikowych w wyniku sufiksacji, prefiksacji, zmiany paradygmatu, dezintegracji, kompozycji - posługiwania się złożeniami i zrostami ${ }^{12}$.

$\mathrm{Na}$ uwagę zasługuje również posługiwanie się analogią słowotwórczą. Proces ten sprzyjał pomnażaniu zasobów leksykalnych polszczyzny od czasów najdawniejszych, jak twierdzi Ewa Rogowska-Cybulska: „analogia słowotwórcza charakteryzuje się dziś szybszym niż dawniej tempem rozwoju ilościowego i jakościowego oraz większym stopniem wewnętrznego skomplikowania formalnego i/lub semantycznego i/lub funkcjonalnego" (Rogowska-Cybulska 2009a: 419). Tworzenie nowych wyrazów z wykorzystaniem formalnych skojarzeń $z$ jednostkami już istniejącymi w języku jest obecnie chętnie wykorzystywane.

Warto także wspomnieć o roli, którą odgrywa grafia w procesie kreatywności leksykalnej. Barbara Kudra pisze, że „we współczesnej komunikacji daje się zauważyć, iż znaki wizualne są skuteczniejsze niż symbole słowne" (Kudra 2007a: 155). Z tego faktu zdają sobie sprawę nadawcy i z chęcią wplatają do tekstów pisanych przykuwające wzrok znaki i symbole graficzne, posługują się różnymi krojami i kolorami czcionek, wykorzystują nawiasy czy służące dekompozycji dywizy, wyróżniają fragmenty słów wersalikami. Celem takich zabiegów jest proste i czytelne zobrazowanie niektórych skomplikowanych często zjawisk. Symbolami posłużono się w następujących przykładach:

€urorozterki - o rozważaniach nt. wprowadzenia waluty euro (P 4/2009, s. 45); € + eurorozterki. Kultur@w sieci - o pierwszym miejscu dla strony internetowej Biblioteki Narodowej w rankingu przeprowadzonym na zlecenie Ministerstwa Kultury (GW 14.07.2009, s. 13); kultura + @ .

SMEGA - wywiad z matematykiem Gregorym Chaitinem o świecie prawdziwej matematyki (P Niezbędnik Inteligenta 8/2009, s. 24); $\Omega$ + omega.

Popularne są także połączenia cyfr i liter wykorzystujące amerykański sposób zapisu. W analizowanym przykładzie konstrukcja z cyfrą „3” nie tylko realizuje się w warstwie fonetycznej (ț̌̌ymamy), ale dodatkowo uwypukla trzecią rocznicę otwarcia sklepu:

${ }^{12}$ Wymienione zjawiska zostały szczegółowo opisanie w przywoływanej już książce B. Kudry (2001). 
3mamy najniższe ceny - gazetka reklamowa Electro World z okazji trzech lat istnienia sklepu w Łodzi; trzymamy +3 .

Różnorodne zabiegi graficzne mogą służyć dekompozycji, czyli procesowi rozkładu wyrazów. W tym celu wykorzystuje się dywiz, wielkie litery czy spacje, np.:

Auto OdNowa - reklama prasowa nowego programu oferowanego przez autoryzowane serwisy Opla dla aut po gwarancji; odnowa + od + nowa.

e-mocje - o olbrzymich kolejkach przed Agencją Rozwoju Przedsiębiorczości, w których czekały osoby składające wnioski na dotacje unijne (od 20 tys. do miliona złotych) dla firm prowadzących e-biznes w Internecie (F TVN, 26.10.2009); emocje + e-.

tele-nowela - o głosowaniu nad nową ustawą medialną (F TVN, 24.06.2009); telenowela + nowela.

Węgry czar dasz wakacjom - reklama prasowa Balaton Sound Festiwalu; czardasz + czar + dasz. ŻYWEC ZDRÓJ SMAKO-ŁYK - reklama wody mineralnej smakowej Żywiec Zdrój; smakołyk + łyk.

Jak stwierdza Iwona Burkacka:

Pisownia wykorzystująca wielką literę i łącznik pozwala na reinterpretację wyrazów - ujawnia rzeczywiste lub wyodrębnione niezgodnie z zasadami analizy słowotwórczej człony składowe wyrazów [...]. Te celowo wywoływane skojarzenia mają ułatwić zapamiętanie nazwy, a także, być może, wskazać na to, że jej właściciele mają poczucie humoru (Burkacka 2007: 82).

Autorzy nagłówków prasowych i telewizyjnych chętnie posługują się konstrukcjami $\mathrm{z}$ wykorzystaniem nawiasów - w ten sposób wyodrębniane są fragmenty wyrazów (mamy wówczas do czynienia z kontaminacją) lub całe wyrazy (nawias występuje wówczas jako parenteza) ${ }^{13}$.

Przedstawiona w niniejszym artykule klasyfikacja nie opisuje oczywiście wszystkich typów kreatywności językowej. Na uwagę zasługiwałyby jeszcze chociażby środki składniowe, fleksyjne, semantyczne czy fonetyczne.

$\mathrm{Na}$ koniec warto się zastanowić, jakie cele przyświecają nadawcom budującym swój komunikat w oparciu o kreatywność leksykalną. Wydaje się, że tworzenie haseł reklamowych i nagłówków z wykorzystaniem niekonwencjonalnych zabiegów językowych jest jednym ze sposobów dotarcia do odbiorcy. Stworzenie oryginalnego hasła czy nazwy pozwala na wyróżnienie wśród natłoku informacji. Zabiegi językowe obecne we współczesnych

${ }^{13}$ Szczegółowe omówienie roli, którą odgrywają nawiasy, można odnaleźć w artykule K. Burskiej (2012d). 
tekstach medialnych podporządkowane są celom komunikacyjnym (przekazaniu informacji), estetycznym (skupieniu uwagi odbiorcy na danym tekście i wyróżnieniu go spośród innych dzięki użyciu określonych środków) oraz pragmatycznym (wywołanie określonej reakcji dzięki zastosowaniu danego chwytu) (Florczak 2004: 71). Kreatywne twory leksykalne wpływają na skuteczne oddziaływanie, więc dziennikarze czy copywriterzy posługują się nimi, by wywołać określoną reakcję u odbiorcy; przekazywanie informacji schodzi w tym przypadku na dalszy plan.

\section{Wykaz skrótów}

DF - „Duży Format”.

F TVN - Fakty, TVN.

GW - „Gazeta Wyborcza”.

GW Łódź - łódzki dodatek do „Gazety Wyborczej”.

GW Pieniądze - dodatek do „Gazety Wyborczej” dotyczący finansów.

GW Praca - dodatek do „Gazety Wyborczej” dotyczący pracy.

GW Sport - dodatek do „Gazety Wyborczej” dotyczący sportu.

GW Turystyka - dodatek do „Gazety Wyborczej” dotyczący turystyki.

PN - „Piłka Nożna”.

PN Plus - „Piłka Nożna Plus”.

P - „Polityka”.

W- „Wprost”.

WO - „Wysokie Obcasy”.

\section{Bibliografia}

Anusiewicz J. (1988), Wprowadzenie w problematyke pragmatyki lingwistycznej, „Acta Universitatis Wratislaviensis. Studia Linguistica”, t. 12, s. 3-29.

Badyda E., Maćkiewicz J., Rogowska-Cybulska E. (red.) (2011), Wokót stów i znaczeń IV. Stowotwórstwo a media, Gdańsk.

Bąba S. (1989), Innowacje frazeologiczne wspótczesnej polszczyzny, Poznań.

Błażejewska J. (2000), Językowe śodki perswazji w nagtówkach publikacji politycznych, [w:] K. Michalewski (red.), Regulacyjna funkcja tekstórw, Łódź, s. 140-150.

Bralczyk J. (red.) (2005), Stownik 100 tysięcy potrzebnych stów, Warszawa.

Bralczyk J., Mosiołek-Kłosińska K. (red.) (2000), Jezzyk w mediach masowych, Warszawa.

Burkacka I. (2007), O grach z wielkq literq, [w:] A. Mikołajczuk, R. Pawelec (red.), Na jezykoznawczych ścieżkach. Prace ofiarowane Profesorowi Jerzemu Podrackiemu, Warszawa, s. 76-83.

Burska K. (2012a), „Delikatne musssnięcie”, „MONstrualna dziura”, „OBAMERYKA”, „Futbol w czasach zarazy" - o recepcji nagtówków prasowych i telewizyjnych oraz sloganów reklamowych, „Acta Universitatis Lodziensis. Folia Linguistica”, t. 46, Łódź, s. 28-41. 
Burska K. (2012b), (ko)misja specjalna - o kontaminacjach graficznych we wspótczesnych tekstach medialnych, [w:] M. Kraska, A. Gumowska, J. Wróbel (red.), Między nieobecnościq a nadmiarem. O niedopowiedzeniu i nienasyceniu we wspótczesnej kulturze, Gdańsk, s. 27-36.

Burska K. (2012c), Kontaminacje jedno- $i$ wielowęztowe w nagtówkach prasowych $i$ komunikatach reklamowych, „Acta Universitatis Lodziensis. Folia Linguistica”, t. 46, Łódź, s. 42-52.

Burska K. (2012d), Nawias w funkcji sensotwórczej w tekstach medialnych, [w:] K. Michalewski (red.), Język nowych mediów, Łódź, s. 255-271.

Burska K., Czarnek P. (red.) (2012), Rozrywka w mediach, Łódź.

Burska-Ratajczyk B. (2004), Formacje deminutywno-hipokorystyczne i neologizmy jako źródto humoru (na przyktadzie „Kolekcji” L. J. Kerna), [w:] K. Wojtczuk, A. Wierzbicka (red.), Funkcja emocjonalna jednostek jezykowych i tekstowych, Siedlce, s. 29-38.

Burska-Ratajczyk B. (2006), „Skibq w mur”-zwiqzki frazeologiczne jako środek wyrażania emocji w felietonach Krzysztofa Skiby, [w:] K. Wojtczuk, V. Machnicka (red.), Wokót jezzykowej funkcji emocjonalnej. Fakty dawne i wspótczesne, Siedlce, s. 21-32.

Buttler D. (1989), Neologizmy kontaminacyjne a norma dzisiejszej polszczyzny, „Poradnik Językowy", z. 6, s. 429-434.

Buttler D. (2001), Polski dowcip językowy, wyd. 3 uzup., Warszawa.

Chlebda W. (1991), Elementy frazematyki. Wprowadzenie do frazeologii nadawcy, Opole.

Chlebda W. (1996), Frazeologia w reklamie i reklama we frazeologii, [w:] A. M. Lewicki (red.), Problemy frazeologii europejskiej, t. 1, Warszawa, s. 57-68.

Chlebda W. (1997), W stronę frazeologii pragmatycznej, „Poradnik Językowy”, z. 2, s. 1-10.

Chlebda W. (2001), Frazematyka, [w:] J. Bartmiński (red.), Wspótczesny język polski, Lublin, s. $327-334$.

Cienkowski W. (1978), Zagadnienia definicji, analizy i klasyfikacji kontaminacji leksykalnych, [w:] Z polskich studiów slawistycznych, Seria 5: Językoznawstwo. Prace na VII Międzynarodowy Kongres Slawistów w Zagrzebiu 1978, Warszawa, s. 351-356.

Dabert D. (1999), Czytelnik uwiedziony. Forma jezykowa tytutów „Gazety Wyborczej”, „Odra”, nr 2, s. 7-14; nr 3, s. 17-24.

Dunaj B. (red.) (1996), Stownik wspótczesnego języka polskiego, Warszawa.

Florczak J. (2004), Zasady funkcjonowania chwytów typograficznych w tekstach o charakterze perswazyjnym, „Biuletyn Polskiego Towarzystwa Językoznawczego”, z. LX, s. 71-88.

Frankowski S. (1997), Frazeologia i metaforyka potoczna w nagtówkach prasowych, „Acta Universitatis Nicolai Copernici. Filologia Polska”, t. XII, z. 80, s. 129-138.

Gajda S. (1987), Spoteczna determinacja nazw wtasnych, „Socjolingwistyka”, t. 6, s. 79-89.

Gajda S., Balowski M. (red.) (1996), Styl a tekst. Materiaty międzynarodowej konferencji naukowej, Opole, 26-28 września 1995 r., Opole.

Głowiński M. (1992), O intertekstualności, [w:] tenże, Poetyka i okolice, Warszawa, s. 87-124.

Głowiński M., Kostkiewiczowa T., Okopień-Sławińska A., Sławiński J. (2000), Stownik terminów literackich, wyd. 3, popr. i rozsz., Wrocław.

Grabias S. (1970), Kontaminacje we wspótczesnym języku polskim. Próba charakterystyki, „Annales UMCS. Sectio F”, t. 25, nr 6, s. 117-145.

Grabias S. (1980), O ekspresywności języka. Ekspresja a stowotwórstwo, Lublin.

Grochala B. (2002), Intertekstualnośc w nagtówkach „Gazety Wyborczej”, [w:] K. Michalewski (red.), Tekst w mediach, Łódź, s. 222-229.

Grzegorczykowa R. (1995), Jak rozumieć kreatywny charakter języka, [w:] A. M. Lewicki, R. Tokarski (red.), Kreowanie świata w tekstach, Lublin, s. 13-24. 
Guz B. (2001), Język wchodzi w gre - o grach językowych na przyktadzie sloganów reklamowych, nagtówków prasowych i tekstów graffiti, „Poradnik Językowy”, z. 10, s. 9-20.

Guziuk B. (1980), Redukcja, nominalizacja i defrazeologizacja zwiq̨zów frazeologicznych w nagtówkach prasowych, „Zeszyty Językoznawcze UMCS”, s. 43-52.

Jachimowska K. (2001), Funkcje frazeologizmów i ich przeksztatceń formalno-znaczeniowych w tekstach telerwizyjnych, [w:] K. Michalewski (red.), Wspótczesna leksyka, cz. 1, Łódź, s. 90-98.

Jawniuk-Pałuszyńska E. (2001), Nazwy wtasne w nagtówkach prasowych jako wyznaczniki funkcji ekspresywnej (na materiale związków frazeologicznych), [w:] K. Michalewski (red.), Wspótczesna leksyka, cz. 1, Łódź, s. 99-109.

Jędrzejko E., Żydek-Bednarczuk U. (red.) (1997), Gry wjęzyku, literaturze i kulturze, Warszawa.

Kacprzak A. (2002), Palimpsesty stowne w jezyku mediów, [w:] K. Michalewski (red.), Tekst w mediach, Łódź, s. 46-52.

Klemensiewicz Z. (1969), O tzw. przejęzyczeniach, [w:] tenże, Ze studiów nad językiem i stylem, Warszawa, s. 29-35.

Kopertowska D. (2000), Ostatni będa pieszymi - czyli o transformacji statych potaczeń wyrazowych we wspótczesnej reklamie, „Prace Filologiczne”, t. XLV, Warszawa, s. 291-299.

Kopertowska D. (2001), Kontaminacja jako jeden ze sposobów modyfikowania związków frazeologicznych na użytek reklamy, „Slavia Occidentalis”, t. 58, s. 19-25.

Kowalewska-Dąbrowska J. (2007a), Gry językowe w tekstach publicystycznych. Kreacja czy manipulacja?, [w:] P. Nowak, R. Tokarski (red.), Kreowanie światów w języku mediów, Lublin, s. 87-105.

Kowalewska-Dąbrowska J. (2007b), Rola perswazyjna gier językowych w tekstach publicystycznych, [w:] V. Maldjieva, Z. Rudzik-Karwatowa (red.), Stowotwórstwo i tekst, Warszawa, s. 79-87.

Kozłowska E. (1996), Kreatywność leksykalna w języku środowiskowym uczniów, [w:] E. Sękowska (red.), Świadomośc językowa - kompetencja - dydaktyka. Materiaty ogólnopolskiej konferencji „Z badan nad kompetencja i świadomościq językowa dzieci i mtodzieży”, Warszawa 25-26 listopada 1994 r., Warszawa, s. 81-89.

Krawiec L. (1989), Komizm w nagtówkach prasowych, „Poradnik Językowy”, z. 9-10, s. 649-653.

Kudra B. (1996), Sposoby porwstawania prasowych okazjonalizmów politycznych, „Poradnik Językowy", z. 8, s. 35-44.

Kudra B. (1997), O sposobach realizacji funkcji perswazyjnej w stownictwie z zakresu polityki, „Rozprawy Komisji Językowej Łódzkiego Towarzystwa Naukowego”, t. XII, s. 169-176.

Kudra B. (2001a), Kreatywność leksykalna w dyskursie politycznym polskiej prasy lat osiemdziesiatych $i$ dziewięćdziesiątych, Łódź.

Kudra B. (2001b), Rola aluzji leksykalnej w procesie tworzenia nowego stownictwa politycznego (na przyktadzie wspótczesnej prasy), [w:] K. Michalewski (red.), Wspótczesna leksyka, cz. 1, Łódź, s. 168-174.

Kudra B. (2007a), Grafizacja w nagłórwkach prasowych, [w:] A. Mikołajczuk, R. Pawelec (red.), Na jezzkoznawczych ścieżkach. Prace ofiarowane Profesorowi Jerzemu Podrackiemu, Warszawa, s. $155-158$.

Kudra B. (2007b), Stowotwórstwo a perswazja, [w:] V. Maldjieva, Z. Rudnik-Karwatowa (red.), Stowotwórstwo i tekst, „Prace Slawistyczne”, nr 124, Warszawa.

Kudra B. (2011), O tzw. derywacji pragmatycznej i derywatach pragmatycznych (stowotwórstwo a pragmatyka), [w:] E. Badyda, J. Maćkiewicz, E. Rogowska-Cybulska (red.), Wokót stów i znaczeń, t. IV: Stowotwórstwo a media, Gdańsk, s. 13-18. 
Kudra B., Kudra A. (2002), Gry intertekstualne na przyktadzie telewizyjnego programu satyrycznego „Ale plama”, [w:] K. Michalewski (red.), Tekst w mediach, Łódź, s. 500-513.

Lewicki A. M. (1995), Frazeologizmy w sloganach reklamowych (reklama prasowa), [w:] A. M. Lewicki, R. Tokarski (red.), Kreowanie swiata w tekstach, Lublin, s. 215-228.

Lewicki A. M. (1996), Wszystko na sprzedaż. Frazeologizmy jako tworzywo sloganów reklamowych, [w:] tenże (red.), Problemy frazeologii europejskiej, t. 1, Warszawa, s. 69-79.

Lewicki A. M. (2004), Nagtówki w formie ustalonych zwiq̨zów wyrazowych jako narzędzie manipulacji, [w:] P. Krzyżanowski, P. Nowak (red.), Manipulacja w języku, Lublin 2004, s. 101-113.

Lewicki A. M., Tokarski R. (red.) (1995), Kreowanie świata w tekstach, Lublin.

Loewe I. (1997), Reklama zaprasza do gry, czyli czym, jak i o co gra się w tekście reklamowym, [w:] E. Jędrzejko, U. Żydek-Bednarczuk (red.), Gry w jezyku, literaturze i kulturze, Warszawa, s. 99-108.

Majkowska G. (1996a), Funkcje frazeologizmów w tekstach publicystycznych, [w:] A. M. Lewicki (red.), Problemy frazeologii europejskiej, t. 1, Warszawa, s. 39-47.

Majkowska G. (1996b), Zajawki, potocyzmy, wtórne nominacje, „Regiony”, nr 3, s. 109-117.

Majkowska G. (1998), Klasyfikacja semantyczna zamierzonych modyfikacji związów frazeologicznych, [w:] M. Basaj, D. Rytel (red.), Z problemów frazeologii polskiej i stowianskiej $V$, Wrocław, s. 143-163.

Makiewicz M. (2007), Innowacja graficzna jako sktadnik wizualizacji semantyki w nagtówkach „Gazety Wyborczej”, „Acta Universitatis Lodziensis. Folia Linguistica”, t. 44, s. 88-103.

Michalewski K. (red.) (2000), Regulacyjna funkcja tekstórw, Łódź.

Michalewski K. (red.) (2001), Wspótczesna leksyka, cz. 1-2, Łódź.

Michalewski K. (red.) (2002), Tekst w mediach, Łódź.

Michalewski K. (red.) (2004), Wspótczesne odmiany języka narodowego, Łódź.

Michalewski K. (red.) (2012), Język nowych mediów, Łódź.

Mikołajczuk A., Pawelec R. (red.) (2007), Na językoznawczych ścieżkach. Prace ofiarowane Profesorowi Jerzemu Podrackiemu, Warszawa.

Miodek J. (1981), Tytut w tytule jako środek stylistyczny, „Rozprawy Komisji Językowej”, t. XII, Wrocławskie Towarzystwo Naukowe, s. 121-129.

Murdoch A. (2004), Kreatywnośc w reklamie, Warszawa.

Nagórko A. (2007), Kontaminacje leksykalne - stowotwórstwo czy radosna tfurczośc??, „Przegląd Humanistyczny”, nr 1, s. 203-211.

Nowak P., Tokarski R. (red.) (2007), Kreowanie światów w języku mediów, Lublin.

Ochmann D. (1997), Prasowe kontaminacje leksykalne (Analiza strukturalna), „Język Polski”, z. 2-3, s. 131-144.

Ochmann D. (2002), Między dezintegracja a analogia. O pewnym typie ztożeń wspótczesnej polszczyzny, „Język Polski”, z. 5, s. 322-329.

Ochmann D. (2004), Nowe wyrazy ztożone o podstawie zdezintegrowanej w jezyku polskim, Kraków.

Ochmann D. (2009), Ztożenia kontaminacyjne we wspótczesnym języku polskim, [w:] M. Skarżyński, M. Szpiczatowska (red.), W kręu języka. Materiaty konferencji „Stowotwórstwo - stownictwo - polszczyzna kresowa" poświęconej pamięci Profesor Zofii Kurzowej, Kraków, 16-17 maja 2008 r., Kraków, s. 293-299.

Ostromęcka-Frączak B. (2008), Kontaminacje jako źródto gier stownych, [w:] A. Kwiatkowska, S. Dżereń-Głowacka (red.), Humor. Teorie - praktyka - zastosowania, t. 1/1: Odcienie bumoru, Piotrków Trybunalski, s. 11-21. 
Piętkowa R. (1996), Wizualizacja semantyki. O niektórych sposobach zapisu we wspótczesnych tekstach, [w:] S. Gajda, M. Balowski (red.), Styl a tekst. Materiaty międzynarodowej konferencji naukowej, Opole, 26-28 września 1995 r., Opole, s. 159-168.

Pisarek W. (red.) (1999), Polszczyzna 2000. Orędzie o stanie języka na przetomie tysiącleci, Kraków.

Ratajczyk K. (2012), Wybrane zjawiska językowe we wspótczesnych mediach jako przejaw uatrakcyjnienia przekazu, [w:] K. Michalewski (red.), Jezzyk nowych mediów, Łódź, s. 348-354.

Rogowska-Cybulska E. (2009a), O analogii stowotwórczej jako jednym z mechanizmów rozwoju leksykalnego wspótczesnej polszczyzny, [w:] D. Bieńkowska, A. Lenartowicz (red.), Tajemnice rozwoju. Materiaty z konferencji 10-12 maja, Łódź, s. 419-430.

Rogowska-Cybulska E. (2009b), Stowotwórstwo w tekstach reklam, [w:] A. Rypel, D. Jastrzębska-Golonka, G. Sawicka (red.), Język, biznes, media, t. XIX, Bydgoszcz, s. 321-332.

Rossowski J. (1937/1938), Etymologie dziecinne i kontaminacje, „Poradnik Językowy”, z. 1-3, s. 8-9.

Rypel A., Jastrzębska-Golonka D., Sawicka G. (red.) (2009), Język, biznes, media, t. XIX, Bydgoszcz.

Satkiewicz H. (1996a), Jeszcze o kontaminacjach frazeologicznych, „Poradnik Językowy”, z. 10, s. $82-83$.

Satkiewicz H. (1996b), Kontaminacja a synonimia we frazeologii, „Poradnik Językowy”, z. 9, s. $75-76$.

Sobol E. (red.) (2000), Maty stownik jezzyka polskiego, Warszawa.

Szczerbowski T. (1994), O grach jezzykowych w tekstach polskiego i rosyjskiego kabaretu lat osiemdziesiatych, Kraków.

Szymczak M. (red.) (1999), Stownik języka polskiego PWN, Warszawa.

Szyszko U. (2000), Gry językowe w sloganach reklamowych, „Język Polski”, z. 2/3, s. 228-232.

Ślawska M. (2008), Tytut-najmniejszy tekst prasowy, „Rocznik Prasoznawczy”, R. II, s. 117-126.

Wojtczuk K., Machnicka V. (red.) (2006), Wokót językorwej funkcji emocjonalnej. Fakty dawne $i$ wspótczesne, Siedlce.

Zagórski Z. (1973), W sprawie kontaminacji, „Studia Polonistyczne UAM”, t. 1, s. 133-143.

Zagórski Z. (1985), Jeszcze w sprawie kontaminacji, „Studia Polonistyczne UAM”, t. 13, s. 69-83.

Zagórski Z. (1989), Kontaminacja a zjawiska pokrewne, „Slavia Occidentalis”, t. 45, s. 91-98. 